\title{
Distributional patterns of deep-sea coral assemblages in three submarine canyons off Newfoundland, Canada
}

\author{
Krista D. Baker ${ }^{1, *}$, Vonda E. Wareham ${ }^{3}$, Paul V. R. Snelgrove ${ }^{1}$, \\ Richard L. Haedrich ${ }^{1}$, David A. Fifield ${ }^{4}$, Evan N. Edinger ${ }^{1,2}$, Kent D. Gilkinson ${ }^{3}$ \\ ${ }^{1}$ Biology Department and ${ }^{2}$ Geography Department, Memorial University of Newfoundland, St. John's, \\ Newfoundland A1B 3X9, Canada \\ ${ }^{3}$ Fisheries \& Oceans Canada, Northwest Atlantic Fisheries Centre, St. John's, Newfoundland A1C 5X1, Canada \\ ${ }^{4}$ Cognitive \& Behavioural Ecology Program, Memorial University of Newfoundland, St. John's, Newfoundland A1B 3X7, \\ Canada
}

\begin{abstract}
Deep-sea corals are fragile and long-lived species that provide important habitat for a variety of taxa. The rarity of in situ observations in deep waters off Newfoundland, Canada, motivated the first extensive deep-sea research cruise to that region in 2007 . We conducted 7 dives in 3 canyons (Haddock Channel, Halibut Channel, and Desbarres Canyon) with ROPOS (Remotely Operated Platform for Ocean Science). Over 160000 coral colonies were enumerated and, of the 28 species found, Acanella arbuscula, Pennatula spp., and Flabellum spp. were most frequently observed. The largest coral observed was Keratoisis grayi at over $2 \mathrm{~m}$ in height. Corals spanned the entire depth range sampled (351 to $2245 \mathrm{~m}$ ) and inhabited all bottom types surveyed, but boulder and cobble habitats were most species-rich. Assemblages differed significantly with depth class and bottom type. The unique assemblage at outcrops was strongly driven by the presence of Desmophyllum dianthus. Keratoisis grayi, D. dianthus, and Anthomastus spp. were largely absent in mud-sand habitats. Sea pen meadows covered large tracts of muddy seafloor spanning $>1 \mathrm{~km}$. Acanella arbuscula and Flabellum spp. characterised large coral fields with abundant corals but relatively low species richness. These results highlight not only the importance of hard structure in determining patterns of coral distributions, abundances, and assemblages, but also the need to focus conservation efforts on a variety of habitats to ensure protection for the full suite of deep-sea coral species.
\end{abstract}

KEY WORDS: Deep-sea corals $\cdot$ Assemblage patterns $\cdot$ Abundance $\cdot$ Conservation

\section{INTRODUCTION}

Deep-sea corals are long lived, slow growing, and highly vulnerable to fishing gear damage (Roberts et al. 2006, 2009, Edinger et al. 2007a, Althaus et al. 2009, Roark et al. 2009, Sherwood \& Edinger 2009), climate change, and ocean acidification (Turley et al. 2007, Guinotte \& Fabry 2008, Hall-Spencer et al. 2008). Corals create feeding habitats, shelter, surfaces for attachment, and simple structural complex- ity for other organisms including fish (Husebo et al. 2002, Ross \& Quattrini 2007, Buhl-Mortensen et al. 2010), echinoderms (Krieger \& Wing 2002), polychaetes (Schembri et al. 2007, Fiege \& Barnich 2009), crustaceans (Krieger \& Wing 2002), and other invertebrates (Krieger \& Wing 2002, Roberts \& Hirshfield 2004). Deep-sea coral habitats often have greater species diversity than surrounding areas and host unique assemblages (Henry \& Roberts 2007, Ross \& Quattrini 2007). These characteristics underscore the 
importance of understanding distribution patterns of deep-sea corals for planning appropriate ocean conservation measures.

The rapid growth of knowledge on deep-sea coral distributions has focused largely on specific regions or sites (Roberts et al. 2005) and associated research tends to concentrate on scleractinian coral reefs (Fossa et al. 2002, Cordes et al. 2008). Coral research in the deep waters off Newfoundland and Labrador is still in its infancy, but substantial knowledge and data began to accumulate from these previously unknown deep waters when dedicated deep-sea coral research began in this region in 2003 (e.g. Edinger et al. 2007a,b, Wareham \& Edinger 2007, Gilkinson \& Edinger 2009, Murillo et al. 2010). These biogeographic and ecological studies concentrated on results from broad-scale trawl surveys and/or bycatch from fisheries observer programs. Video studies in 2002 examined deep-sea corals on the slope of the Southwest Grand Banks, but covered only a few $\mathrm{km}$ of bottom to a maximum depth of $500 \mathrm{~m}$ (Mortensen et al. 2006a,b). Therefore, little information is available on deep-sea coral distributions and patterns on small spatial scales for this region and in situ observations of deep-sea corals are rare. Fine-scale, in situ observations would allow better understanding of local patterns of distribution, changes in abundance, assemblages, associations with other taxa, and impacts of deep-sea fishing.

Like most marine organisms, deep-sea corals have preferred depth distributions and habitat characteristics. Temperature, salinity, substrate, currents, and slope all contribute to distributional trends and levels of abundance (Roberts et al. 2009). For example, in Atlantic Canada, Mortensen et al. (2006b) found Flabellum spp. on primarily muddy substratum and most coral species occurred between 4.5 and $6.0^{\circ} \mathrm{C}$. In a submarine canyon off Nova Scotia, Keratoisis grayi and Duva florida were associated with steep topography and semi-consolidated mudstone (Mortensen \& Buhl-Mortensen 2005).

Most previous deep-sea coral studies focused on individual distributions of species and few examined patterns in composition among and between coral communities and species' co-occurrences. Understanding these facets of coral ecology would allow development of more appropriate conservation actions that recognize the importance of unique and/or diverse communities above and beyond individual species.

We present here the results of the first extensive, in situ study of deep-sea corals on the Newfoundland continental slope, and describe the distributions and abundances of the observed species, assemblages, and species diversity with respect to bottom type, depth, and study area. We increase the known distribution, depth range, and abundance concentrations for multiple species and genera, and conclude by describing how this new knowledge may facilitate deep-sea conservation planning.

\section{MATERIALS AND METHODS}

\section{Video surveys}

We focused on 3 submarine canyons on the slopes of the Grand Banks south of Newfoundland: Halibut Channel, Haddock Channel, and Desbarres Canyon (Fig. 1). A small bank separates Halibut Channel and Haddock Channel, which are situated $\sim 110$ and $175 \mathrm{~km}$ east of Laurentian Channel, and 150 and $200 \mathrm{~km}$ northwest of Desbarres Canyon, respectively. The cold Labrador Current from the north and the warm Gulf Stream from the south both influence the study area. Temperature regimes were similar in the 3 canyons, with an average bottom temperature of $\sim 5^{\circ} \mathrm{C}$ during relatively shallow dives $(<1100 \mathrm{~m})$ and $\sim 4.4^{\circ} \mathrm{C}$ during relatively deep dives $(>1100 \mathrm{~m})$. Bottom current measurements taken in Haddock Chan-

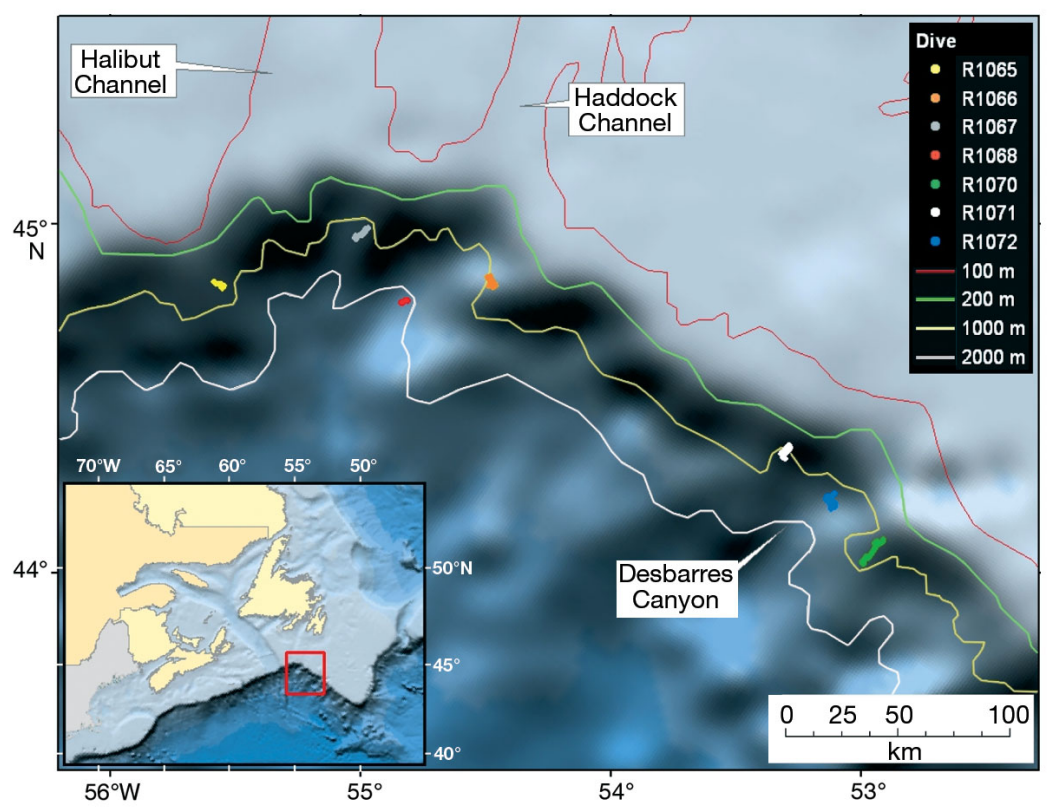

Fig. 1. Location of ROV dive sites during a 2007 cruise off Newfoundland, Canada 
nel $(\sim 700 \mathrm{~m})$ indicated relatively slow current speeds (5 to $10 \mathrm{~cm} \mathrm{~s}^{-1}$ ), compared to previously studied coral habitats on the slope of the Scotian Shelf (e.g. Northeast Channel, The Gully, Stone Fence) (Zedel \& Fowler 2009). Data from Fisheries and Oceans Canada surveys and bycatch records suggested species-rich and abundant corals at these 3 sites.

The remotely operated vehicle (ROV), ROPOS (Remotely Operated Platform for Ocean Science) (CSSF 2010), performed video surveys from CCGS 'Hudson' during 7 dives between 16 and 24 July 2007 (Table 1). Lasers on the ROV placed $10 \mathrm{~cm}$ apart indicated scale. Depth, date, time, altitude (distance above bottom), temperature, and position were logged at 1-s intervals, though sporadic problems with the logger resulted in several long periods with no temperature data.

Based on known distributions of corals and bathymetry from previous work, we planned 1-km transects every $200 \mathrm{~m}$ of depth along depth contours between 2200 and $500 \mathrm{~m}$ and along contours every $100 \mathrm{~m}$ in waters shallower than $500 \mathrm{~m}$ (Fig. 1). We standardized transects by keeping the ROV as close to the bottom as possible, maintaining a constant slow speed ( 0.2 to $\left.0.3 \mathrm{~m} \mathrm{~s}^{-1}\right)$ while tilting the camera down slightly on a wide-angle view in order to image the seafloor and water column directly above. Between pre-selected transects, we explored the area with ROPOS, capturing still images and video of interesting features, and collecting physical specimens to validate visual identification.

\section{Video processing}

Using the program ClassAct Mapper (Benjamin 2007), we continuously recorded geo-referenced data describing bottom type, ROV behaviour, and corals. All corals were identified to the lowest possible taxonomic level and the colony height and diameter of

Table 1. ROV cruise dives off Newfoundland in 2007, associated depths, time on bottom, and distance covered

\begin{tabular}{|lcccc|}
\hline Dive & Date & $\begin{array}{c}\text { Depth } \\
\text { range }(\mathrm{m})\end{array}$ & $\begin{array}{c}\text { Time on } \\
\text { bottom (h) }\end{array}$ & $\begin{array}{c}\text { Distance } \\
(\mathrm{km})\end{array}$ \\
\hline R1065 & 16-17 July & $606-1015$ & 12.6 & 10.7 \\
R1066 & 17-18 July & $493-1020$ & 16.0 & 15.8 \\
R1067 & 18-19 July & $395-996$ & 10.2 & 13.4 \\
R1068 & 19 July & 1990-2245 & 4.5 & 5.9 \\
R1070 & 21 July & $351-940$ & 15.5 & 23.6 \\
R1071 & 22-23 July & $353-1174$ & 12.8 & 16.9 \\
R1072 & 23-24 July & 1116-1900 & 18.8 & 19.0 \\
Total & & & 90.4 & 105.3 \\
\hline
\end{tabular}

relatively large corals (antipatharians, Isididae, Paramuricea spp., and other gorgonians) were measured to the nearest $5 \mathrm{~cm}$ using the lasers for scale.

We characterized bottom type every second by primary (most abundant) substrate and secondary (next most abundant) substrate, with optional additional comments. We categorized bottom type as (1) outcrop (vertically exposed bedrock and consolidated Quaternary sediment), (2) boulder (>25 cm), (3) cobble $(5-25 \mathrm{~cm})$, (4) gravel $(0.2-5 \mathrm{~cm})$, or (5) mud-sand (fine-grain) sediments (Thrush et al. 2001). For example, a bottom type description might consist of mudsand as the primary bottom type and gravel as the secondary bottom type, with 'scattered boulders' as an additional comment.

ROV behaviour was categorized at $1 \mathrm{~s}$ intervals as transect-mode, benthic-mode, sampling, too high, stationary viewing, panning, or view obstruction. 'Transect-mode' was defined as any portion of the video when the ROV followed the prescribed methodology for transects (described above), regardless of whether the transect was planned. 'Benthic-mode' described periods when the ROV moved forward with a clear view of the seafloor and the camera pointed directly toward the sediment. 'Sampling' denoted any sections of the video during which sampling occurred and 'stationary-viewing' denoted periods when we stopped the ROV to view a feature of interest. 'Panning' described situations when the ROV moved forward, but with the camera at an inconsistent angle or position. 'View obstruction' occurred when other sampling gear (e.g. pushcore handles) obstructed part of the camera view.

\section{Data analysis}

We characterized survey sites according to depth, duration, and distance surveyed and used transect segments to describe bottom type. We illustrated the overall characteristics of the habitats surveyed by plotting bottom type versus depth for each second of data when the ROV moved forward with a clear view of the seafloor (i.e. transect-mode, benthic-mode, and panning). All dead corals in the video were noted, but because live coral communities were the focus of this study, we removed dead corals from the analyses.

\section{Species composition and occurrence}

We described the overall distribution and composition of corals by calculating the number of colonies 
and their sizes for each species (or species group) and by examining occurrence of each species in relation to depth.

For more detailed analyses of patterns, we focused on those species identified to the lowest possible taxonomic level. For example, we excluded gorgonians that could not be identified to a unique genus from further analysis. We could easily distinguish one species of Pennatula (Pennatula sp. 1) during video processing, but combined all other Pennatula into Pennatula spp., so that the abundant 'unknown Pennatula' could be included in analyses. For the same reason, we combined all Flabellum into the single category Flabellum spp.

We assigned a single bottom type to each 1-s observation based on the premise that hard structure can influence the coral assemblage regardless of its prevalence. Therefore, bottom type was categorized as the largest sediment structure for each 1-s observation. For example, if a given observation included the bottom type categories of cobble (primary), boulders (secondary), and scattered gravel (comments), we assigned it the bottom type 'boulders'. We found one large fishing net in an otherwise muddy habitat that created attachment structure for several coral species, so we removed this portion of the data from analyses involving bottom type. We then examined coral occurrence in relation to bottom type and depth.

We split video data collected in transect mode into a series of 10-m segments (samples). For each sample, we defined bottom type as the largest structure encountered during the 10-m segment and depth as the mean depth recorded within the segment. Coral abundance was calculated as the number of colonies per sample and this value was used to investigate maximum abundance for each species (or species group).

We used the 10-m segments to examine patterns in coral richness by calculating species richness for each sample and comparing among dive locations, depth categories, and bottom types. We defined depth categories based on the distribution of corals and the number of samples in each category: (1) 300-800 m, (2) 800-1300 m, and (3) 1300-2300 m. Patterns in richness among bottom types were compared graphically using box-plots.

\section{Assemblages}

We determined patterns in assemblages within the samples using Primer 6.0 (Clarke \& Gorley 2006) analyses of square-root transformed data to reduce the influence of abundant species. A Bray-Curtis similarity matrix was used to conduct a 2-way analysis of similarities (ANOSIM) test for differences in assemblages between and within samples. We examined species similarities (and dissimilarities) within and between depth classes and bottom types in SIMPER (similarity percentages).

We examined similarities between species by creating a Bray-Curtis species similarity matrix of standardized samples and species that contributed at least $50 \%$ to a sample. We then produced a multidimensional scaling (MDS) plot and dendrogram (using group average clustering) based on these similarities.

Table 2. Number of $10-\mathrm{m}$ transect segments in each dive, in relation to depth categories and bottom types

\begin{tabular}{|c|c|c|c|c|c|c|c|c|c|}
\hline \multirow{2}{*}{ Depth (m) } & \multirow{2}{*}{$\begin{array}{l}\text { Bottom } \\
\text { type }\end{array}$} & \multicolumn{7}{|c|}{ - ROPOS dive number } & \multirow{2}{*}{ Total } \\
\hline & & R1065 & R1066 & R1067 & R1068 & R1070 & R1071 & R1072 & \\
\hline \multirow[t]{5}{*}{$300-800$} & Mud-sand & 159 & 192 & 14 & - & 490 & 371 & - & 1226 \\
\hline & Gravel & & 35 & 8 & - & 56 & 9 & - & 108 \\
\hline & Cobble & 98 & 345 & 320 & - & 223 & 54 & - & 1040 \\
\hline & Boulders & 30 & 75 & 124 & - & 7 & 17 & - & 253 \\
\hline & Outcrop & - & - & 1 & - & - & - & - & 1 \\
\hline \multirow[t]{5}{*}{$800-1300$} & Mud-sand & 200 & 203 & 103 & - & 507 & 289 & 246 & 1548 \\
\hline & Gravel & 2 & - & - & - & - & - & - & 2 \\
\hline & Cobble & 14 & - & 1 & - & - & - & - & 15 \\
\hline & Boulders & 4 & - & - & - & - & - & 3 & 7 \\
\hline & Outcrop & - & - & 2 & - & - & - & - & 2 \\
\hline \multirow[t]{4}{*}{$1300-2300$} & Mud-sand & - & - & - & 101 & - & - & 640 & 741 \\
\hline & Gravel & - & - & - & 69 & - & - & 6 & 75 \\
\hline & Cobble & - & - & - & 7 & - & - & - & 7 \\
\hline & Outcrop & - & - & - & - & - & - & 6 & 6 \\
\hline Total & & 507 & 850 & 573 & 177 & 1283 & 740 & 901 & 5031 \\
\hline
\end{tabular}




\section{RESULTS}

In total, we recorded $90 \mathrm{~h}$ of bottom video footage over the 7 dives, covering a distance of $\sim 105 \mathrm{~km}$ (Table 1) and a depth range of 351 to $2245 \mathrm{~m}$. We recorded 5031 samples (10-m transect segments) over a variety of habitats and depth categories (Table 2). Most transect segments were over mud-sand habitats (Fig. 2) within the 300-800 m depth category. Boulders were rare in deep waters and outcrops were rare over the entire depth range. Dive R1070 produced the most samples $(\mathrm{n}=901)$.

\section{Species composition and occurrence}

We recorded over 160000 coral colonies, comprising at least 28 distinct species (Table 3). Although we identified Flabellum macandrewi, F. alabastrum, and $F$. angulare from specimens collected during the cruise, these species were usually grouped as Flabellum spp. in the video analysis. The most abundant species were Pennatula sp. 2 (possibly $P$. aculata), Acanella arbuscula, Flabellum spp. and Acanthogorgia armata. The maximum number of a single species observed in a 10-m segment was Pennatula spp. (622 colonies), followed by Flabellum spp. (300 individuals), and Heteropolypus cf. insolitus (123 colonies) (Table 4). Rare species included antipatharians, Lepidisis sp., and Paragorgia arborea.

The tallest coral colony observed was a Keratoisis grayi colony measuring $215 \mathrm{~cm}$ in height. Although rare, antipatharians were fairly large, one exceeding $60 \mathrm{~cm}$ in height. Of the 3 Paragorgia arborea observed, 2 were only $\sim 5 \mathrm{~cm}$ in height, whereas the largest colony was only $\sim 20 \mathrm{~cm}$. The abundant corals Acanella arbuscula and Acanthogorgia armata both averaged almost $10 \mathrm{~cm}$ in height.

Many species spanned a wide depth range and appeared unrestricted by depth (Fig. 3). This pattern was especially true for many of the sea pens (e.g. Protoptilum carpenteri, Anthoptilum grandiflorum, and Halipteris finmarch-

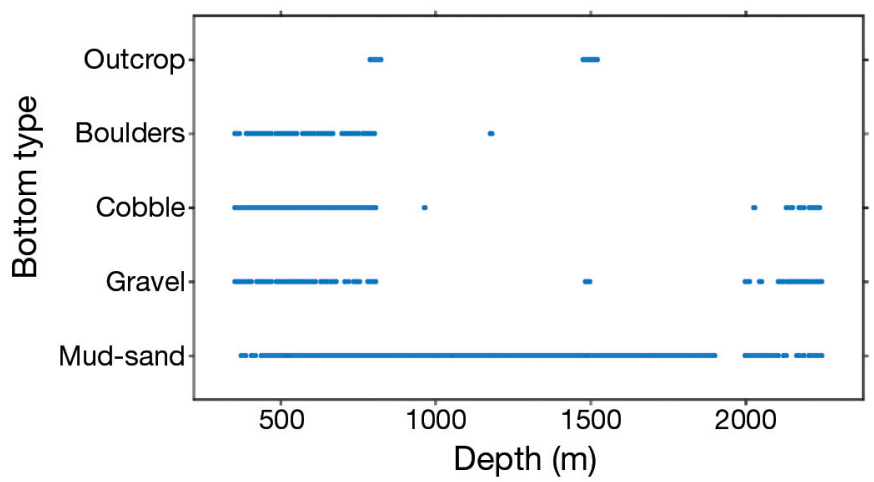

Fig. 2. Depth and sediment type surveyed off the Grand Banks, Newfoundland during the 2007 in situ survey. Each point: $1 \mathrm{~s}$ of video footage while the remotely operated vehicle moved forward with an unobstructed view of the seafloor

Table 3. Taxonomic composition, abundance, and heights of coral colonies found off the Grand Banks, Newfoundland during the 2007 in situ survey

\begin{tabular}{|c|c|c|c|}
\hline Coral group & Species & $\begin{array}{l}\text { Number } \\
\text { observed }\end{array}$ & $\begin{array}{l}\text { Max. / Av. } \\
\text { height }(\mathrm{cm})\end{array}$ \\
\hline Antipatharians & $\begin{array}{l}\text { Bathypathes patula } \\
\text { Schizopathidae n. gen. et n. sp. } \\
\text { Antipatharian (unknown) }\end{array}$ & $\begin{array}{l}1 \\
2 \\
1\end{array}$ & $\begin{array}{c}15 \\
>60 / 58 \\
50\end{array}$ \\
\hline Scleractinians & $\begin{array}{l}\text { Vaughanella sp. } \\
\text { Desmophyllum dianthus } \\
\text { Flabellum alabastrum } \\
\text { Flabellum macandrewi } \\
\text { Flabellum spp. } \\
\text { Javania cailleti } \\
\text { Scleractinian (unknown) }\end{array}$ & $\begin{array}{r}7 \\
143 \\
6965 \\
320 \\
7894 \\
4 \\
5\end{array}$ & \\
\hline Gorgonians & $\begin{array}{l}\text { Keratoisis grayi } \\
\text { Lepidisis sp. } \\
\text { Acanella arbuscula } \\
\text { Isididae (unknown) } \\
\text { Paramuricea spp. } \\
\text { Paragorgia arborea } \\
\text { Radicipes gracilis } \\
\text { Chrysogorgia agassizii } \\
\text { Acanthogorgia armata } \\
\text { Gorgonian (unknown) }\end{array}$ & $\begin{array}{r}5116 \\
1 \\
24334 \\
3 \\
32 \\
3 \\
212 \\
80 \\
7688 \\
2\end{array}$ & $\begin{array}{c}215 \text { / } 37 \\
30 \\
30 / 9 \\
30 / 30 \\
45 / 15 \\
20 / 12 \\
30 / 13 \\
51 / 8 \\
50 / 38\end{array}$ \\
\hline Alcyonaceans & $\begin{array}{l}\text { Anthomastus spp. } \\
\text { Heteropolypus cf. insolitus } \\
\text { Duva florida } \\
\text { Neptheidae (unknown) }\end{array}$ & $\begin{array}{r}3239 \\
4869 \\
232 \\
417\end{array}$ & \\
\hline Pennatulaceans & $\begin{array}{l}\text { Anthoptilum grandiflorum } \\
\text { Funiculina quadrangularis } \\
\text { Halipteris finmarchica } \\
\text { Kophobelemnon stelliferum } \\
\text { Pennatula grandis } \\
\text { Pennatula sp. } 1 \\
\text { Pennatula sp. } 2 \\
\text { Pennatula (unknown) } \\
\text { Protoptilum carpenteri } \\
\text { Distichoptilum gracile } \\
\text { Umbellula spp. } \\
\text { Pennatulacea (unknown) }\end{array}$ & $\begin{array}{r}355 \\
4694 \\
1681 \\
1812 \\
6032 \\
152 \\
67752 \\
11350 \\
3086 \\
665 \\
20 \\
2220\end{array}$ & \\
\hline Unknown & Coral (unknown) & 11 & \\
\hline
\end{tabular}


ica). The distribution of Flabellum alabastrum spanned nearly $1900 \mathrm{~m}$ (355 to $2244 \mathrm{~m}$ ), resulting in the widest depth range of all coral species observed;

Table 4. Maximum abundance of corals, its depth and dive number in 10-m transect segments. Abundances with a maximum of 1 are not included

\begin{tabular}{|llrrr|}
\hline Coral group & Species & $\begin{array}{c}\text { Maximum } \\
\text { abundance }\end{array}$ & $\begin{array}{c}\text { Depth } \\
(\mathrm{m})\end{array}$ & Dive \\
\hline Scleractinians & Desmophyllum dianthus & 61 & 1506 & R1072 \\
& Flabellum spp. & 300 & 380 & R1070 \\
& Keratoisis grayi & 43 & 573 & R1067 \\
& Acanella arbuscula & 77 & 639 & R1065 \\
& Paramuricea spp. & 3 & 664 & R1065 \\
& Radicipes gracilis & 31 & 1427 & R1072 \\
& Chrysogorgia agassizii & 3 & 2243 & R1068 \\
& Acanthogorgia armata & 36 & 540 & R1066 \\
& Anthomastus spp. & 54 & 573 & R1067 \\
& Heteropolypus cf. insolitus & 123 & 611 & R1070 \\
& Duva florida & 35 & 406 & R1070 \\
& Anthoptilum grandiflorum & 3 & 843 & R1070 \\
& Funiculina quadrangularis & 17 & 930 & R1070 \\
& Halipteris finmarchica & 12 & 437 & R1071 \\
& Kophobelemnon stelliferum & 13 & 585 & R1071 \\
& Pennatula sp. 1 & 7 & 912 & R1071 \\
& Pennatula spp. & 622 & 835 & R1071 \\
& Protoptilum carpenteri & 9 & 993 & R1071 \\
& Distichoptilum gracile & 4 & 1323 & R1072 \\
& Distichoptilum gracile & 4 & 1294 & R1072 \\
& & & \\
& & &
\end{tabular}

however $H$. finmarchica also spanned a considerable depth range (353 to $2217 \mathrm{~m}$ ). Very few species were restricted to deep water, although Chrysogorgia agassizii was limited to depths $>1997 \mathrm{~m}$ and the single colony of Bathypathes patula was found at $2242 \mathrm{~m}$. In comparision, many more species were limited to the upper and middle slope, including all Pennatula spp. (<1204 m), Keratoisis grayi $(<967 \mathrm{~m})$, Duva florida $(<906 \mathrm{~m})$, and Paragorgia arborea $(<800 \mathrm{~m})$.

Most corals occurred in a variety of bottom types, but several appeared to be restricted in relation to bottom type (Fig. 4). Javania cailleti, Desmophyllum dianthus, Paragorgia arborea, and Schizopathidae n. gen. et $\mathrm{n}$. sp. occurred only in areas with large, hard substratum. Paramuricea spp., Keratoisis grayi, and Anthomastus spp. were mostly limited to areas with hard substratum, but that bottom type ranged in size and included small substrate, such as gravel. In comparison, Distichoptilum gracile, Umbellula spp., Bathypathes patula, and Kophobelemnon

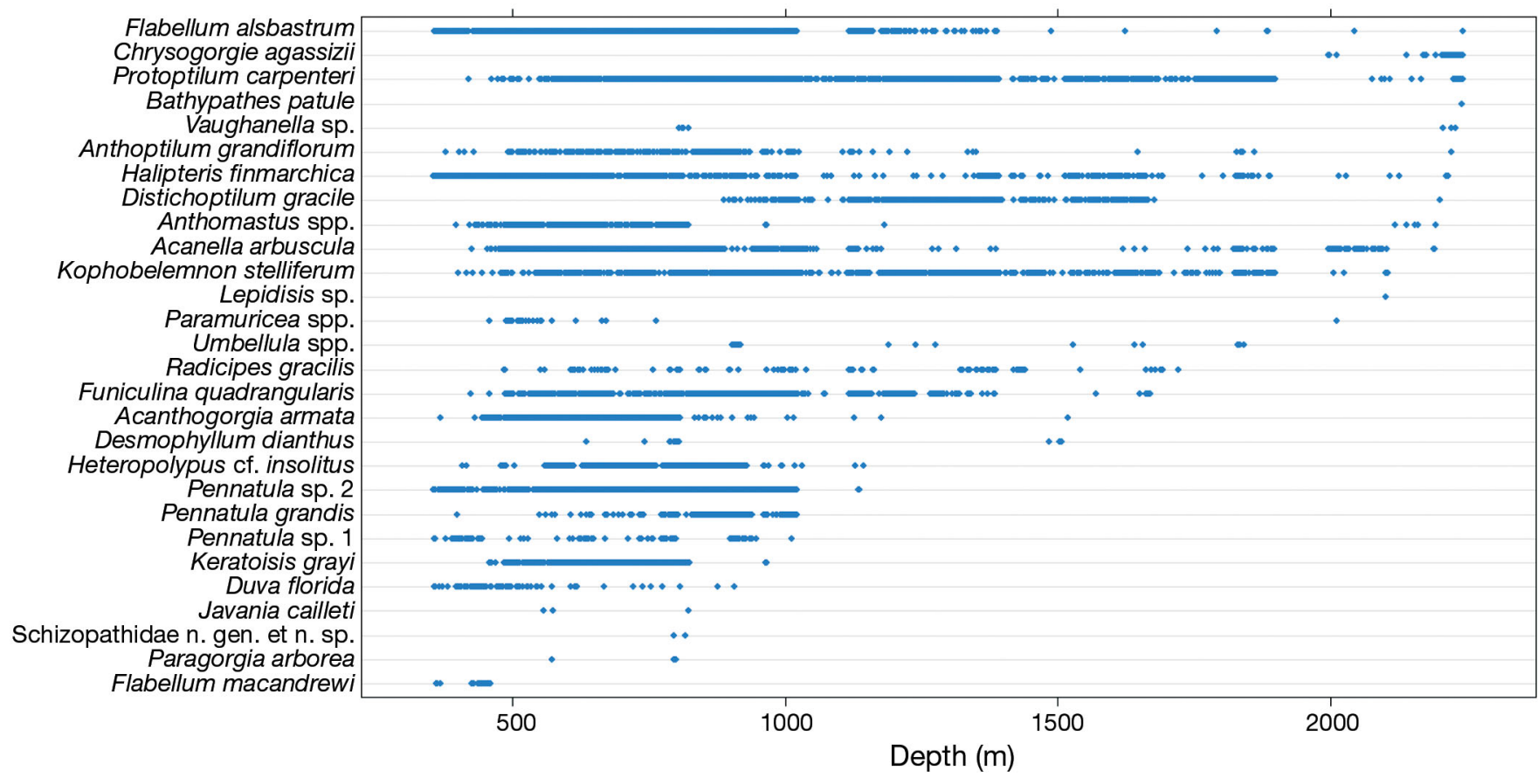

Fig. 3. Depth distributions of coral species observed off the Grand Banks of Newfoundland during the 2007 in situ survey. Each point: single coral observation 


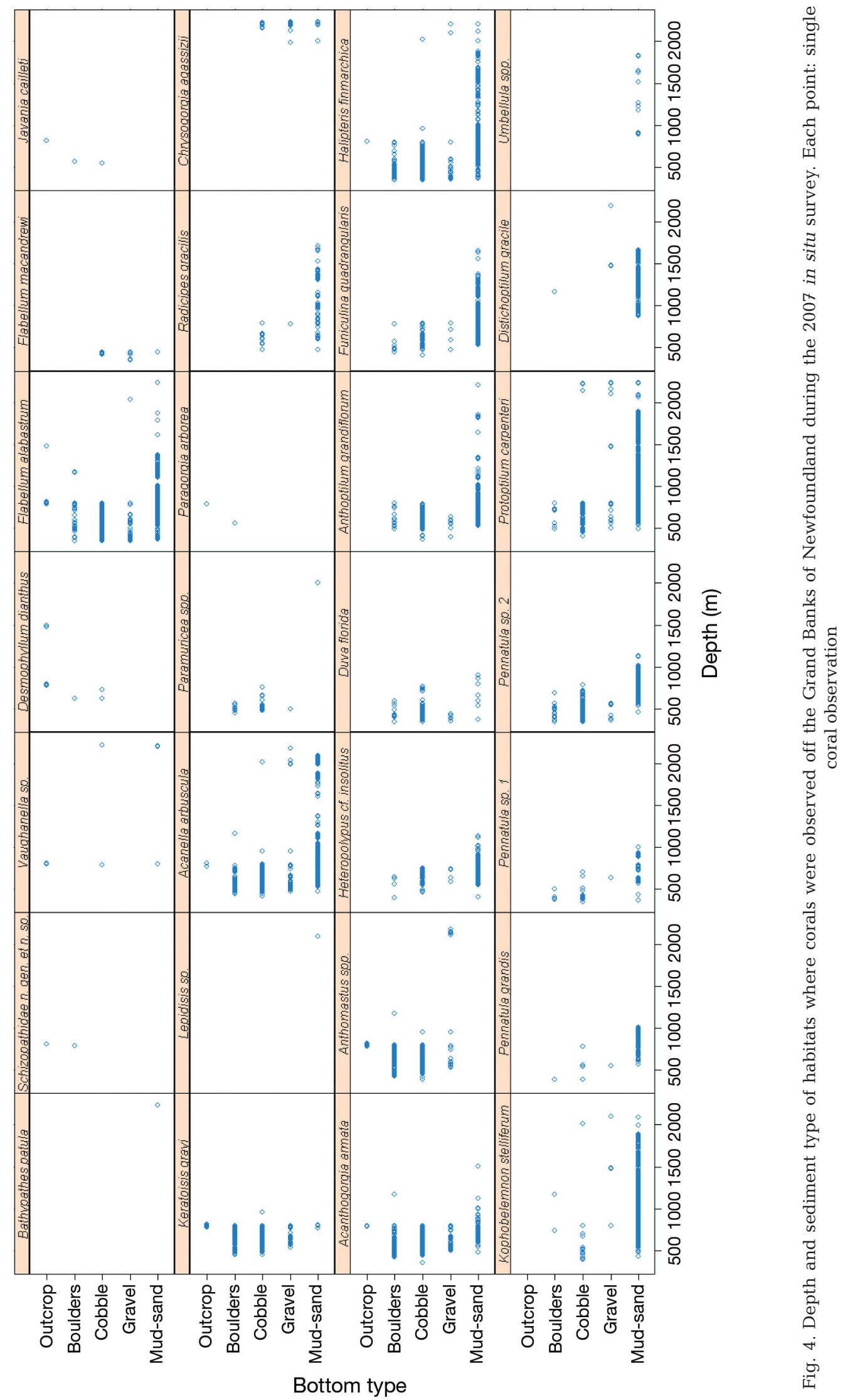




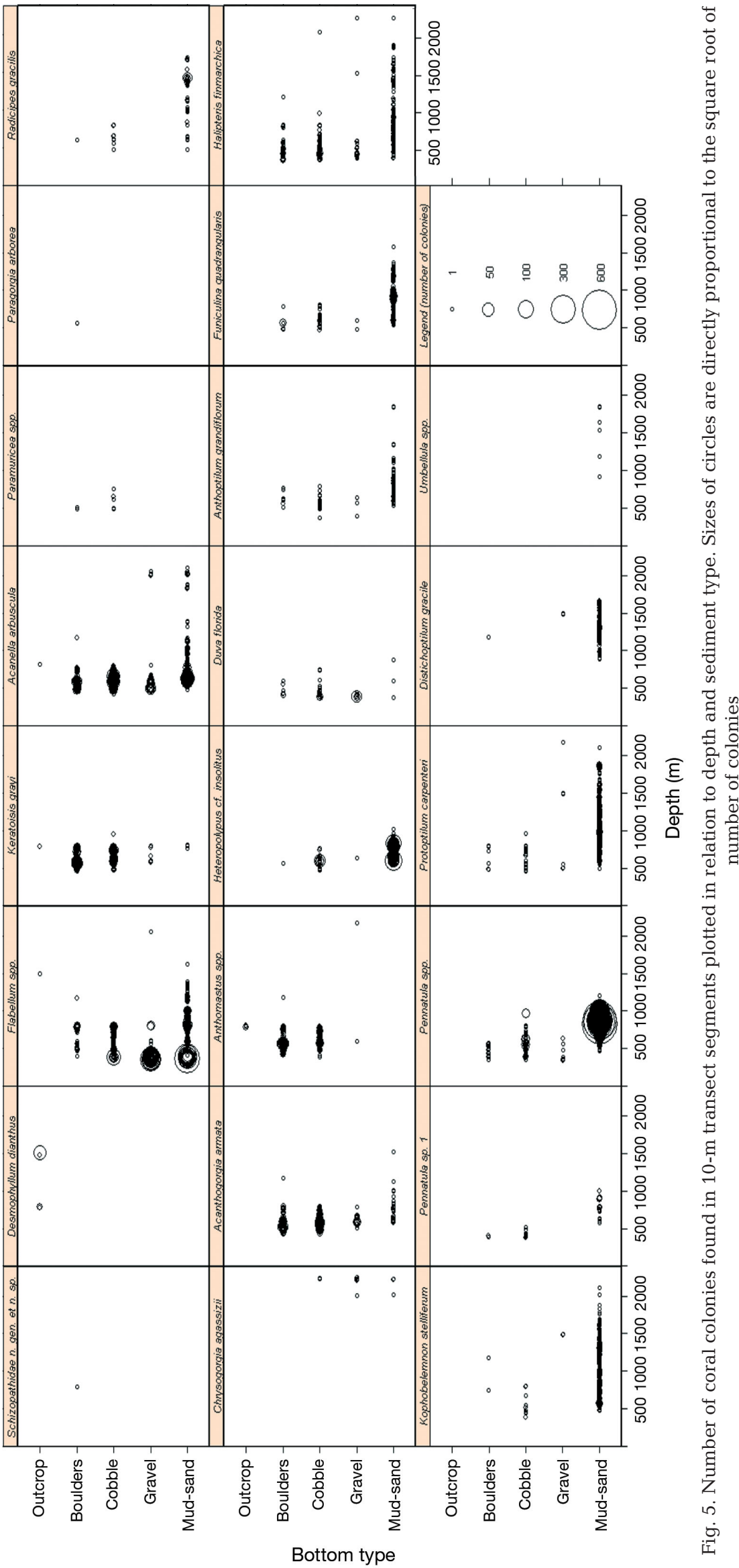

stelliferum occurred primarily in soft sediments. Species that spanned a wide variety of bottom types included Flabellum alabastrum, Acanella arbuscula, Acanthogorgia armata and others.

Although many species spanned a variety of bottom types and depths, when we plotted their abundances within 10-m transect segments against bottom type and depth, several patterns emerged (Fig. 5). For example, Flabellum spp. spanned a large depth range, but were most dense in waters $<500 \mathrm{~m}$. Although Heteropolypus cf. insolitus and Pennatula spp. spanned a variety of bottom types, they were much more abundant in mud-sand sediments than in bottom types categorized by hard substratum.

In general, species richness was highest in boulder areas (Fig. 6). The maximum species richness within any sample $(7$ species $)$ occurred twice in boulders (489 and $470 \mathrm{~m}$, Halibut Channel) and once in cobble $(600 \mathrm{~m}$, Haddock Channel) (Table 5). The maximum number of coral colonies was associated with mud-sand sediments $(835 \mathrm{~m})$ in Desbarres Canyon (Table 5), but only 3 of these were colonies other than Pennatula spp.

\section{Assemblages}

The global ANOSIM showed assemblages that differed significantly among depth classes $(p<0.001)$ and pairwise comparisons showed significant differences between each depth class $(p<0.001)$ (Table 6). However, the R-statistic indicated that assemblage composition differed most between depth ranges 300-800 and 1300-2300 $\mathrm{m}(\mathrm{R}=$ 0.471 ). This dissimilarity (average dissimilarity $=92.6 \%$ ) was largely driven by higher abundances of Acanella arbuscula and Pennatula spp. in shallower waters. Pennatula 


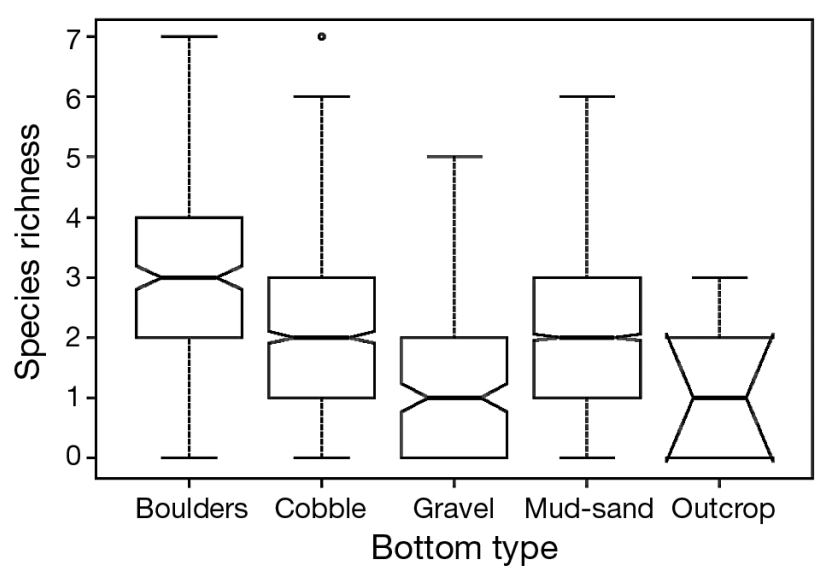

Fig. 6. Species richness in relation to sediment type from $10-\mathrm{m}$ transect segments recorded by an ROV off Newfoundland, Canada in 2007. Median, upper/ lower quartiles, minimum/maximum values, and an outlier are shown

Table 5. Maximum species richness and number of coral colonies in 10-m transect segments in a variety of habitat categories

\begin{tabular}{|lccc|}
\hline & $\begin{array}{c}\text { Habitat } \\
\text { category }\end{array}$ & $\begin{array}{c}\text { Maximum } \\
\text { species } \\
\text { richness }\end{array}$ & $\begin{array}{c}\text { Maximum } \\
\text { number of } \\
\text { colonies }\end{array}$ \\
\hline Sediment type & Outcrop & 3 & 61 \\
& Boulders & 7 & 99 \\
& Cobble & 7 & 82 \\
& Gravel & 5 & 200 \\
& Mud-sand & 6 & 625 \\
Depth category $(\mathrm{m})$ & $300-800$ & 7 & 301 \\
& $800-1300$ & 6 & 625 \\
& $1300-2300$ & 4 & 61 \\
& R1065 & 6 & 79 \\
Rive & R1066 & 7 & 183 \\
& R1067 & 7 & 99 \\
& R1068 & 2 & 4 \\
& R1070 & 6 & 301 \\
& R1071 & 6 & 625 \\
& R1072 & 5 & 61 \\
\hline
\end{tabular}

spp. and $A$. arbuscula also drove differences between the 300-800 and 800-1300 m assemblages (average dissimilarity $=85 \%$ ); Pennatula spp. was most abundant in the 800-1300 m depth class, whereas $A$. arbuscula was more abundant in the 300-800 m depth class. The assemblage differences between the 800-1300 and 1300-2300 m depth classes (average dissimilarity $=88 \%$ ) were largely driven by Pennatula spp. and Protoptilum carpenteri. Pennatula spp. occurred in the shallower depth range but not in deeper waters and $P$. carpenteri was more abundant in the deeper depth class compared to the shallower depth range.
Table 6. Results from 2-way analysis of similarity (ANOSIM) to compare coral assemblages between depths and sediment types from an ROV survey off the Grand Banks in 2007

\begin{tabular}{|lccc|}
\hline Comparison group & $\begin{array}{c}\mathrm{R} \\
\text { statistic }\end{array}$ & $\begin{array}{c}\text { Level of } \\
\text { signifi- } \\
\text { cance (p) }\end{array}$ & $\begin{array}{c}\text { Permuta- } \\
\text { tions }> \\
\mathrm{R}\end{array}$ \\
\hline Depth, global test & 0.302 & 0.001 & 0 \\
300-800, 800-1300 m & 0.239 & 0.001 & 0 \\
300-800, 1300-2300 m & 0.471 & 0.001 & 0 \\
800-1300, 1300-2300 m & 0.292 & 0.001 & 0 \\
Sediment type, global test & 0.224 & 0.001 & 0 \\
Mud-sand, Boulders & 0.316 & 0.001 & 0 \\
Mud-sand, Cobble & 0.171 & 0.001 & 0 \\
Mud-sand, Gravel & 0.222 & 0.001 & 0 \\
Mud-sand, Outcrop & 0.552 & 0.001 & 0 \\
Boulders, Cobble & 0.073 & 0.001 & 0 \\
Boulders, Gravel & 0.440 & 0.001 & 0 \\
Boulders, Outcrop & 0.560 & 0.069 & 68 \\
Cobble, Gravel & 0.191 & 0.001 & 0 \\
Cobble, Outcrop & 0.585 & 0.020 & 19 \\
Gravel, Outcrop & 0.466 & 0.001 & 0 \\
\hline
\end{tabular}

The ANOSIM analysis showed significant differences in composition among bottom types $(p<0.001)$ (Table 6). Mud-sand sediment assemblages differed from those associated with boulders $(\mathrm{R}=0.316, \mathrm{p}<$ $0.001)$ and outcrops $(\mathrm{R}=0.552, \mathrm{p}<0.001)$. Assemblages in boulder habitats also differed from those in gravel $(\mathrm{R}=0.440, \mathrm{p}<0.001)$ and outcrops $(\mathrm{R}=0.56$, $\mathrm{p}=0.069$ ), but not from assemblages associated with cobble $(\mathrm{R}=0.073)$. Coral assemblages on outcrops also differed from those in cobble $(R=0.585, p=0.02)$ and gravel $(\mathrm{R}=0.466, \mathrm{p}<0.001)$ habitats.

Generally, the paucity of species in mud-sand habitats had the greatest influence on assemblage dissimilarities. For example, fine sediments lacked Keratoisis grayi, Desmophyllum dianthus, and Anthomastus spp., and abundances of Flabellum spp. and Acanella arbuscula were lower than in areas with hard substrate like boulders (average dissimilarity $=86.9 \%)$ and outcrops $(99.31 \%)$. The high dissimilarity of coral assemblages between boulders and outcrops $(87.3 \%)$ was largely driven by low abundances of $K$. grayi on outcrops and the absence of $D$. dianthus from boulder habitats. The higher abundance of Flabellum spp. contributed most to the dissimilarities between boulders and gravel (84.2\%). The low abundance of $A$. arbuscula and high abundance of $D$. dianthus associated with outcrops drove dissimilarities with cobble $(95.0 \%)$. Unlike outcrops, gravel had abundant Flabellum spp., but lacked D. dianthus (99.2\%).

Species similarity analyses grouped Keratoisis grayi, Acanthogorgia armata, and Anthomastus 
spp. in the dendrogram (Fig. 7) and MDS plot (Fig. 8), indicating regular co-occurrence. Acanella arbuscula and Flabellum spp. also grouped closely in the MDS plot. Desmophyllum dianthus, Chrysogorgia agassizi, Pennatula sp. 1, Umbellula spp., and Radicipes gracilis were generally not associated with other species in the plot. The dendrogram showed the same species as outliers and illustrated groupings (albeit with relatively weak similarity of $\sim 20 \%$ ) of Kophobelemnon stelliferum and Protoptilum carpenteri, and Funiculina quadrangularis and Pennatula spp.

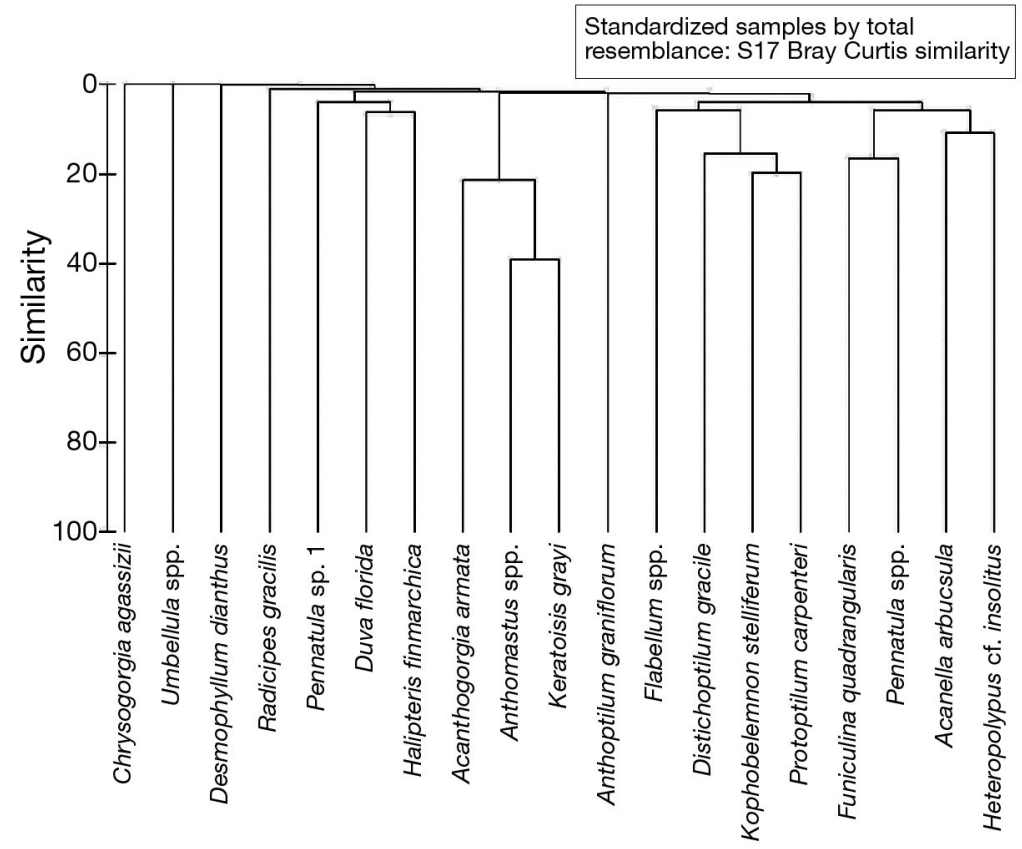

Fig. 7. Dendrogram of species, using group-average clustering from BrayCurtis similarities on standardized samples. Data collected using an ROV off Newfoundland in 2007

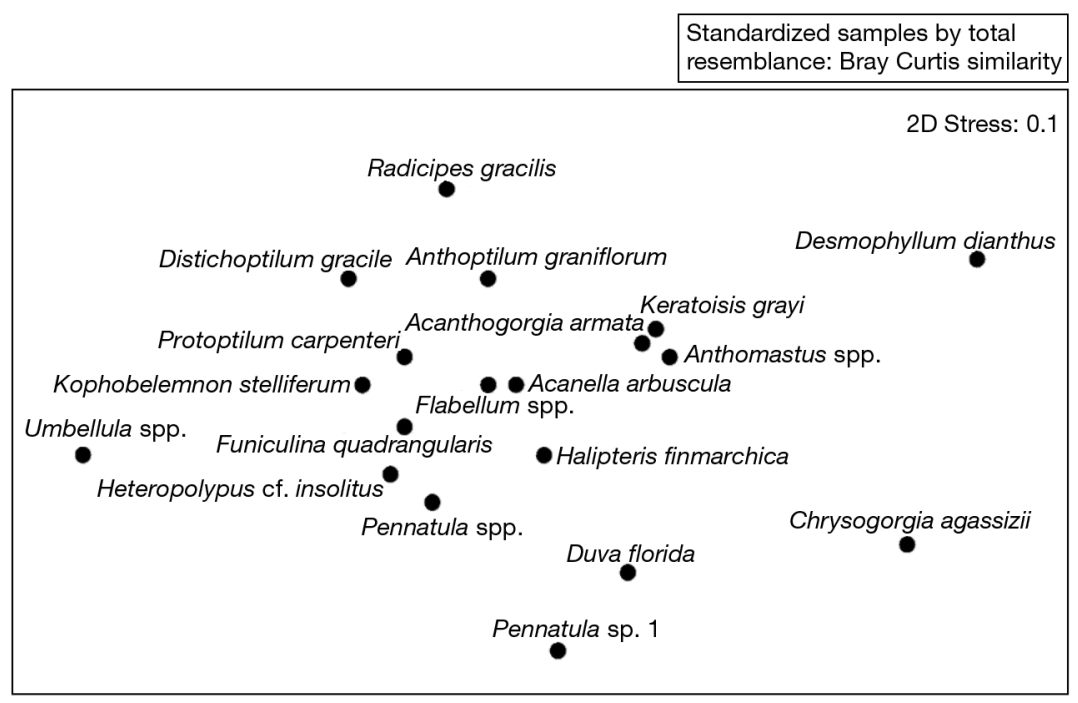

Fig. 8. MDS plot of Bray-Curtis similarity matrix based on standardized samples and species that contribute at least $50 \%$ to a sample. Data collected using an ROV off Newfoundland in 2007

\section{DISCUSSION}

\section{Patterns in species occurrences and abundances}

Bottom type and depth clearly influenced species occurrences and abundance. Physical characteristics of some species explain how bottom type influences their distributions. Peduncles anchor sea pens in sediments, thus largely restricting them to muddy habitats (Williams 2011). Some species can retract into the sediment when disturbed (Packer et al. 2007), elevating their requirement for muddy substrate. We often observed rapid retraction of entire colonies of Protoptilum carpenteri into the sediment, complicating sampling of this species. Although we found sea pens occupied a variety of bottom types, they were almost always anchored in the mud/sand portions of the substratum. The one exception was Halipteris finmarchica, which sometimes anchored in gravelly habitat with little mud or sand. As reported by Mortensen et al. (2006b) and Hecker \& Blechschmidt (1980), holdfast structures anchored Radicipes gracilis and Acanella arbuscula in the soft substratum. Other species, such as Keratoisis grayi, Anthomastus spp., Schizopathidae n. gen. et n. sp. and Duva florida, require hard substrate for attachment (Roberts et al. 2009), and their distributions are therefore limited by hard structure availability.

As reported elsewhere (Packer et al. 2007), Desmophyllum dianthus typically occurred in high abundances on outcrops (Fig. 5). A strong base attaches this cup coral to hard substrate where it can benefit from high currents associated with local topo- 
graphic features (Dolan et al. 2008). Försterra et al. (2005) also recorded $D$. dianthus on vertical walls and the undersides of rock ledges, and they hypothesized the coral's downward facing polyps were caused by sensitivity to sedimentation. Laboratory experiments demonstrate physiological thresholds in corals beyond which they cannot compensate for sedimentation (Brooke et al. 2009). Desmophyllum dianthus strongly influenced the unique assemblage associated with outcrops and thus could be considered an indicator species for vertical clifflike structures in the study region (i.e. large quantities of $D$. dianthus likely indicate outcrop-type substrate).

Many species spanned wide depth ranges, including Flabellum alabastrum, Protoptilum carpenteri, and Halipteris finmarchica. This pattern parallels findings of exceptionally wide depth ranges in corals from the Northeast Pacific Ocean; Antipathidae, Primnoidae, and Paragorgiidae spanned minimum depths shallower than $30 \mathrm{~m}$ to depths $>1900 \mathrm{~m}$ (Etnoyer \& Morgan 2005). The especially wide depth ranges of Pennatulaceans are thought, in part, to reflect their ability to inhabit soft sediments (such as those found in the abyssal plains) (Williams 2011). In contrast to the wide depth ranges of some species, several species in our study, such as Duva florida and Paragorgia arborea, were restricted to shallow depths. The influence of depth on coral distributions likely reflects associated changes in environmental characteristics, such as temperature (Roberts et al. 2009), available bottom type (Fig. 2), and currents.

Temperature is thought to restrict deep-sea coral distributions (Mortensen et al. 2006b, Bryan \& Metaxas 2007, Roberts et al. 2009, Davies \& Guinotte 2011, Waller et al. 2011). For example, high temperatures $\left(>10^{\circ} \mathrm{C}\right)$ may restrict the upper depth limit of Paragorgia arborea off Atlantic Canada (Mortensen et al. 2006b). Given that our study focused on relatively deep waters, the maximum temperatures for each species were well within the temperature ranges recorded by Mortensen et al. (2006b). In comparison to other surveys off Canada that recorded temperature (Mortensen et al. 2006b, Beazley 2011), we extended the known minimum temperature limit in this region for Radicipes gracilis $\left(4.4^{\circ} \mathrm{C}\right)$, Anthomastus spp. $\left(4.3^{\circ} \mathrm{C}\right)$, Acanella arbuscula $\left(3.5^{\circ} \mathrm{C}\right)$, and Flabellum alabastrum $\left(3.7^{\circ} \mathrm{C}\right)$. Nevertheless, because these species are known to occur in higher latitudes and in deeper waters off Atlantic Canada (Fisheries and Oceans Canada [DFO] and K. Baker, unpubl. data), these values likely do not represent their lower temperature limit.

\section{Patterns in community composition and diversity}

Keratoisis grayi, Anthomastus spp., and Acanthogorgia armata co-occurred (Fig. 9a) at relatively
Fig. 9. Photos of coral in ROPOS transects off Newfoundland in 2007. (a) Assemblage of Keratoisis grayi, Anthomastus sp., and Acanthogorgia armata on a small boulder (dive R1065 at $671 \mathrm{~m}$ ) (Flabellum sp. can also be seen), (b) sea pen field (mostly Pennatula spp.) in fine-sediment habitat (R1071, $835 \mathrm{~m})$, (c) close up view of 2 Acanella arbuscula in fine sediments with Sebastes sp. (R1071, $594 \mathrm{~m})$, (d) view of Flabellum spp. in fine sediments (R1065, $946 \mathrm{~m}$ )

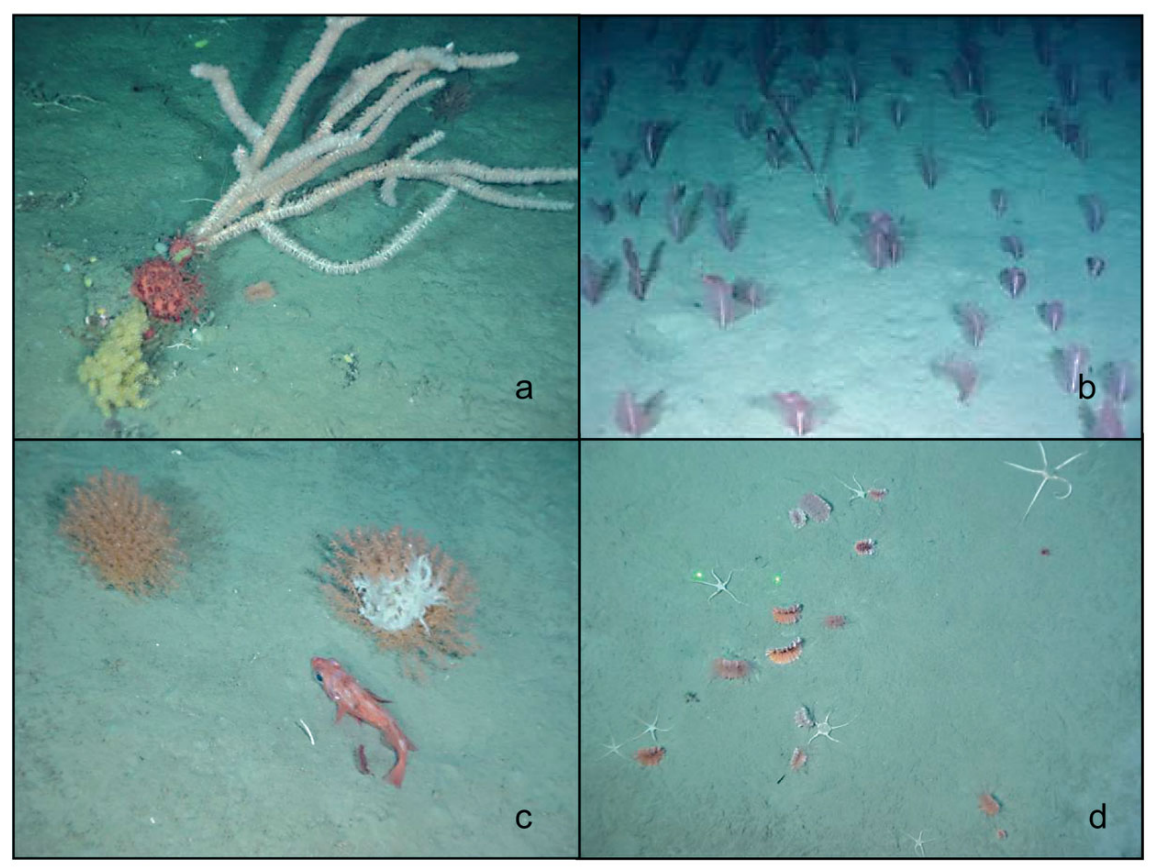


shallow depths with boulders and cobbles throughout Halibut and Haddock Channels. The most species-rich and diverse transects were similar in species composition, comprising of A. armata, Anthomastus spp., K. grayi, Acanella arbuscula, and Halipteris finmarchica among others. The associated bottom types were boulders or cobble, but closer examination of the bottom classification indicated that these assemblages occurred in specific segments of transects with mixed substrate. For example, we recorded sand (primary), boulders (secondary), and scattered cobble/gravel (comments) for one of the most species rich segments. These features created a small-scale habitat mosaic in which a variety of species could co-occur.

The most numerous species occurred within a variety of bottom types and with a variety of other species, but these dominant corals also created unique assemblages in relatively uniform sediments. Pennatula spp. sometimes occurred in large sea pen meadows $>1 \mathrm{~km}$ in length (Fig. 9b), and reached maximum numbers of 622 colonies per $10-\mathrm{m}$ segment. Many colonies oriented in a similar direction (presumably to maximize use of currents) (Roberts et al. 2009). Halipteris finmarchica, Protoptilum carpenteri, Kophobelemnon stelliferum, and other sea pens were scattered throughout these meadows. Although it is unclear what role these meadows play in the wider ecosystem context, their large extent, large number of colonies, and added structure in an otherwise low-structure habitat suggest their presence may be important for other taxa (Tissot et al. 2006). Tissot et al. (2006) hypothesized that aggregations of sea pens may create important refugia for small invertebrates, alter current regimes, and influence prey availability. The sea pen meadows did not appear to host noticeably more abundant or diverse megafauna, but this does not preclude their potential importance for macrofauna or small life stages of mobile megafauna.

Acanella arbuscula (Fig. 9c) or Flabellum spp. (Fig. 9d) also dominated large tracts of seafloor. We observed both types of coral fields in fine sediments, sometimes with scattered gravel. In general, species richness in $A$. arbuscula fields was low with only a few species in any 10-m segment. Sea pens and Flabellum spp. (Fig. 8) were also present in A. arbuscula fields. Low coral species richness ( $\leq 2$ species) also characterized fields with an abundance of Flabellum spp. Although few species were present in these fields, numbers of corals were considerable and appeared to represent unique ecosystems in this area.

\section{Large scale patterns in species distributions and diversity}

We observed at least 28 coral species during the 7 dives. Murillo et al. (2010) found only 17 species on the Grand Banks during their bottom trawl surveys, Mortensen et al. (2006b) identified 12 species on the Grand Banks using a variety of techniques, and Wareham \& Edinger (2007) recorded 30 species throughout all Newfoundland and Labrador waters. In a towed camera survey of more southerly canyons, Hecker et al. (1980) found at least 12 species of corals in Baltimore Canyon, 13 species in Lydonia Canyon, and 16 species in Oceanographer Canyon.

Our study represents the first observations for many deep-sea coral species in Newfoundland waters: Heteropolypus cf. insolitu, Lepidisis sp., Bathypathes patula, Schizopathidae n. gen. et n. sp., Protoptilum carpenteri, Umbellula sp. (likely encrinus), Flabellum macandrewi, and Javania cailleti. Other species found in this study confirm those recorded in extensive fishery and trawl surveys of the Grand Banks and surrounding areas, though several studies did not report Chrysogorgia agassizi (Gass \& Willison 2005, Wareham \& Edinger 2007, Murillo et al. 2010). Our cruise identified at least 3 species of Flabellum, compared to the one (F. alabastrum) recorded by the other survey methods (Wareham \& Edinger 2007, Murillo et al. 2010). Mortensen et al. (2006b) found F. macandrewi along the Scotian Shelf and within The Gully off Nova Scotia, but not off Newfoundland and Labrador. Pennatula aculeata and P. grandis were commonly found in surveys by Murillo et al. (2010), but at least 3 species of Pennatula could be distinguished from our video and require additional taxonomic and genetic work.

\section{Coral size}

Although the tallest Keratoisis grayi was $215 \mathrm{~cm}$, many colonies were greater in width than height (e.g. $160 \times 250 \mathrm{~cm}$ and $200 \times 230 \mathrm{~cm}$ ). The ages and growth rates of corals sampled suggest that the $215 \mathrm{~cm}$ tall $K$. grayi is likely over 200 yr old (Sherwood \& Edinger 2009). The tallest Schizopathidae n. gen. et n. sp. (incorrectly identified as Stauropathes arctica in Sherwood \& Edinger 2009) was over $50 \mathrm{yr}$ old, and the tallest Acanella arbuscula $(30 \mathrm{~cm})$ was $\sim 30$ yr old. These large sizes and slow growth rates highlight the slow recovery times for disturbed coral assemblages and the need for strong conservation measures in the deep sea. 


\section{Conservation implications}

Scientists recognize the importance of protecting deep-sea corals (Roberts \& Hirshfield 2004), which is often achieved through protected areas (Brock et al. 2009). But despite the growing international push for coral protection, no official marine protected areas currently exist off Newfoundland and Labrador to protect deep-sea corals within Canadian waters. Conservation objectives should guide selection of which areas to protect. Many conservation efforts prioritize protection of high concentrations/abundances of corals, high species richness, or unique corals. Our high-resolution video surveys provide in situ observations and highlight patterns that can be used to help guide future conservation initiatives.

If the objective is to protect rare, unique assemblages of corals, our results indicate that known deep-sea outcrops off Newfoundland would be an appropriate starting point, given the relatively rare species for this region present at outcrops, such as Paragorgia arborea, antipatharians, and several species of cup corals. Protection of high coral species richness should concentrate on upper to middle slope areas with a variety of substratum including boulders, cobble, and fine sediments. Selection of areas to protect high abundances of corals varies with species. The middle to upper slope with large areas of relatively hard substrate should be targeted if the goal is to protect large, fragile corals (such as gorgonians and antipatharians). Although conservation priorities should not shift from rarer species, conservation efforts should at least consider common species as well (Gaston 2010). More common species (such as sea pens and Flabellum spp.) tend to be overlooked in conservation initiatives (for example Edinger et al. 2007a, Brock et al. 2009), to the benefit of large, spectacular corals or deep-water coral reefs. The fine sediment habitats where these common species occur contain unique coral assemblages and often have abundant corals.

Nevertheless, we believe the most successful conservation initiative for deep-sea corals off Atlantic Canada would take a holistic approach to conservation planning and use a representative network of protected areas to help conserve a variety of species, assemblages.

In 2008, the Northwest Atlantic Fisheries Organization (NAFO) created a closed area for corals off the slope of the Grand Banks to protect corals from bottom fishing (NAFO 2011). The protection zone runs roughly along the $800-1000 \mathrm{~m}$ isobath crossing into Canada's exclusive economic zone (Rogers \& Gianni
2010). In general, our results show the highest abundance of fragile corals and highest species richness occur on the upper to middle slope, adding to the growing research that indicates this zone is too deep for its intended purpose (Rogers \& Gianni 2010). Therefore, this zone should be extended into shallower waters where corals currently remain at risk to fishing activities.

\section{Future work}

Although this study illuminates general patterns of deep-sea coral occurrence off Newfoundland, the unique sampling problems associated with deep-sea corals necessitates much more in situ research in this region. Studies should aim to collect detailed multibeam bathymetry data (Dolan et al. 2008), geological samples, sedimentation rates, current speed and direction (Mortensen \& Buhl-Mortensen 2004), and temporal and spatial trends in primary productivity to understand better the processes driving coral distributions. Many sites thought to be important for corals based on fishing or trawl survey data (Edinger et al. 2007a) remain unexplored with other methods, constraining any comprehensive understanding of coral abundances, assemblages, and diversity. Meanwhile, deep-water fishing (especially bottom trawling) activities continue to threaten corals, and as long these activities remain our primary data source, destruction will outpace our understanding of coral distributions and assemblage patterns.

Acknowledgements. An NSERC (Natural Sciences and Engineering Research Council of Canada) postgraduate scholarship, NSERC ship time grant, NSERC Discovery Grants, and Fisheries and Oceans Canada provided funding for this research. We sincerely thank the crew from CCGS 'Hudson' and ROPOS for their hard work and dedication. We also thank B. Oake for her help with video analysis and R. Benjamin for his patient explanations of ClassAct Mapper.

\section{LITERATURE CITED}

Althaus F, Williams A, Schlacher TA, Kloser RJ and others (2009) Impacts of bottom trawling on deep-coral ecosystems of seamounts are long-lasting. Mar Ecol Prog Ser 397:279-294

Beazley L (2011) Reproductive biology of the deep-water gorgonian coral Acanella arbuscula from the Northwest Atlantic. MSc thesis, Dalhousie University, Halifax

Benjamin R (2007) ClassAct Mapper. Fisheries and Oceans Canada

Brock R, English E, Kenchington E, Tasker M (2009) The 
alphabet soup that protects cold-water corals in the North Atlantic. Mar Ecol Prog Ser 397:355-360

- Brooke SD, Holmes MW, Young CM (2009) Sediment tolerance of two different morphotypes of the deep-sea coral Lophelia pertusa from the Gulf of Mexico. Mar Ecol Prog Ser 390:137-144

Bryan TL, Metaxas A (2007) Predicting suitable habitat for deep-water gorgonian corals on the Atlantic and Pacific Continental Margins of North America. Mar Ecol Prog Ser 330:113-126

Buhl-Mortensen L, Vanreusel A, Gooday AJ, Levin LA and others (2010) Biological structures as a source of habitat heterogeneity and biodiversity on the deep ocean margins. Mar Ecol 31:21-50

Clarke KR, Gorley RN (2006) PRIMER v6: user manual/tutorial. PRIMER-E, Plymouth

Cordes EE, McGinley MP, Podowski EL, Becker EL and others (2008) Coral communities of the deep Gulf of Mexico. Deep-Sea Res I 55:777-787

CSSF (2010) Canadian Scientific Submersible Facility, available at: www.ropos.com (accessed November)

Davies AJ, Guinotte JM (2011) Global habitat suitability for framework-forming cold-water corals. PLoS One 6(4): e18483

Dolan MFJ, Grehan AJ, Guinan JC, Brown C (2008) Modelling the local distribution of cold-water corals in relation to bathymetric variables: adding spatial context to deepsea video data. Deep-Sea Res I 55:1564-1579

Edinger EN, Baker KD, Devillers R, Wareham V (2007a) Coldwater corals off Newfoundland and Labrador: distribution and fisheries impacts. World Wildlife Fund (WWF), Toronto

Edinger EN, Wareham VE, Haedrich RL (2007b) Patterns of groundfish diversity and abundance in relation to deepsea coral distributions in Newfoundland and Labrador waters. In: George RY, Cairns SD (eds) Conservation and adaptive management of seamount and deep-sea coral ecosystems. Rosenstiel School of Marine and Atmospheric Science, University of Miami, Miami, FL

Etnoyer P, Morgan LE (2005) Habitat-forming deep-sea corals in the Northeast Pacific Ocean. In: Freiwald A, Roberts JM (eds) Cold-water corals and ecosystems. Springer-Verlag, Berlin, p 331-343

Fiege D, Barnich R (2009) Polynoidae (Annelida: Polychaeta) associated with cold-water coral reefs of the northeast Atlantic and the Mediterranean Sea. In: Maciolek NJ, Blake JA (eds) Proc 9th Int Polychaete Conf. Zoosymposia 2:149-164

Försterra G, Beuck L, Haussermann V, Freiwald A (2005) Shallow-water Desmophyllum dianthus (Scleractinia) from Chile: characteristics of the biocoenoses, the bioeroding community, heterotrophic interactions and (paleo)-bathymetric implications. In: Freiwald A, Roberts JM (eds) Cold-water corals and ecosystems. SpringerVerlag, Berlin, p 937-977

- Fossa JH, Mortensen PB, Furevik DM (2002) The deepwater coral Lophelia pertusa in Norwegian waters: distribution and fishery impacts. Hydrobiologia 471:1-12

Gass SE, Willison JHM (2005) An assessment of the distribution of deep-sea corals in Atlantic Canada by using both scientific and local forms of knowledge. In: Freiwald A, Roberts JM (eds) Cold-water corals and ecosystems. Springer-Verlag, Berlin, p 223-245

Gaston KJ (2010) Valuing common species. Science 327: $154-155$
Gilkinson K, Edinger EN (2009) The ecology of deep-sea corals of Newfoundland and Labrador waters: biogeography, life history, biogeochemistry and relation to fishes. Can Tech Rep Fish Aquat Sci 2830

Guinotte JM, Fabry VJ (2008) Ocean acidification and its potential effects on marine ecosystems. Ann NY Acad Sci 1134:320-342

Hall-Spencer JM, Rodolfo-Metalpa R, Martin S, Ransome E and others (2008) Volcanic carbon dioxide vents show ecosystem effects of ocean acidification. Nature 454: 96-99

Hecker B, Blechschmidt G (1980) Appendix A: Epifauna of the Northeastern US Continental Margin. Final historical coral report for the Canyon Assessment Study in the Mid- and North Atlantic areas of the US outer continental shelf. In: Hecker B, Blechschmidt G, Gibson P (eds) Canyon Assessment Study. US Department of Interior Bureau of Land Management, Washington, DC

Hecker B, Blechschmidt G, Gibson P (1980) Epifaunal zonation and community structure in three Mid- and North Atlantic canyons. In: Hecker B, Blechschmidt G, Gibson P (eds) Canyon Assessment Study. US Department of Interior Bureau of Land Management, Washington, DC

Henry LA, Roberts JM (2007) Biodiversity and ecological composition of macrobenthos on cold-water coral mounds and adjacent off-mound habitat in the bathyal Porcupine Seabight, NE Atlantic. Deep-Sea Res I 54: 654-672

Husebo A, Nottestad L, Fossa JH, Furevik DM, Jorgensen SB (2002) Distribution and abundance of fish in deep-sea coral habitats. Hydrobiologia 471:91-99

$>$ Krieger KJ, Wing BL (2002) Megafauna associations with deepwater corals (Primnoa spp.) in the Gulf of Alaska. Hydrobiologia 471:83-90

> Mortensen PB, Buhl-Mortensen L (2004) Distribution of deep-water gorgonian corals in relation to benthic habitat features in the Northeast Channel (Atlantic Canada). Mar Biol 144:1223-1238

Mortensen PB, Buhl-Mortensen L (2005) Deep-water corals and their habitats in The Gully, a submarine canyon off Atlantic Canada. In: Freiwald A, Roberts JM (eds) Coldwater corals and ecosystems. Springer-Verlag, Berlin, p 247-277

Mortensen PB, Buhl-Mortensen L, Gass SE, Gordon DC, Kenchington E, Bourbonnais C, MacIsaac KG (2006a) Deep-water corals in Atlantic Canada: a summary of ESRF-funded Research (2001-2003). Environmental Studies Research Funds Report Vol. 143

Mortensen PB, Buhl-Mortensen L, Gordon DC (2006b) Distribution of deep-water corals in Atlantic Canada. Proc 10th Int Coral Reef Symp, Okinawa 1:1832-1848

Murillo FJ, Durán Muñoz P, Altuna A, Serrano A (2010) Distribution of deep-water corals of the Flemish Cap, Flemish Pass, and the Grand Banks of Newfoundland (Northwest Atlantic Ocean): interaction with fishing activities. ICES J Mar Sci 68:319

NAFO (2011) Northwest Atlantic Fisheries Organization, available at www.nafo.int (accessed 30 September)

Packer D, Boelke D, Guida V, McGee L (2007) State of deep coral ecosystems in the Northeastern US region: Maine to Cape Hatteras. In: Lumsden SE, Hourigan TF, Bruckner A, Dorr G (eds) The state of deep coral ecosystems of the United States. NOAA, Silver Spring, MD

Roark EB, Guilderson TP, Dunbar RB, Fallon SJ, Mucciarone DA (2009) Extreme longevity in proteinaceous deep-sea 
corals. Proc Natl Acad Sci USA 106:5204-5208

Roberts S, Hirshfield M (2004) Deep-sea corals: out of sight, but no longer out of mind. Front Ecol Environ 2:123-130

Roberts JM, Brown CJ, Long D, Bates CR (2005) Acoustic mapping using a multibeam echosounder reveals coldwater coral reefs and surrounding habitats. Coral Reefs 24:654-669

Roberts JM, Wheeler AJ, Freiwald A (2006) Reefs of the deep: the biology and geology of cold-water coral ecosystems. Science 312:543-547

Roberts JM, Wheeler AJ, Freiwald A, Cairns S (2009) Coldwater corals: the biology and geology of deep-sea coral habitats. Cambridge University Press, New York, NY

Rogers A, Gianni M (2010) The implementation of UNGA Resolutions 61/105 and 64/72 in the management of deep-sea fisheries on the high seas. International Programme of the State of the Ocean, London

Ross SW, Quattrini AM (2007) The fish fauna associated with deep coral banks off the southeastern United States. Deep-Sea Res I 54:975-1007

Schembri PJ, Dimech M, Camilleri M, Page R (2007) Living deep-water Lophelia and Madrepora corals in Maltese waters (Strait of Sicily, Mediterranean Sea). Cah Biol Mar 48:77-83

Sherwood OA, Edinger EN (2009) Ages and growth rates of some deep-sea gorgonian and antipatharian corals of Newfoundland and Labrador. Can J Fish Aquat Sci 66: 142-152

Editorial responsibility: Charles Birkeland, Honolulu, Hawaii, USA
Thrush SF, Hewitt JE, Funnell GA, Cummings VJ and others (2001) Fishing disturbance and marine biodiversity: the role of habitat structure in simple soft-sediment systems. Mar Ecol Prog Ser 223:277-286

Tissot BN, Yoklavich MM, Love MS, York K, Amend M (2006) Benthic invertebrates that form habitat on deep banks off southern California, with special reference to deep sea coral. Fish Bull 104:167-181

Turley CM, Roberts JM, Guinotte JM (2007) Corals in deepwater: Will the unseen hand of ocean acidification destroy cold-water ecosystems? Coral Reefs 26:445-448

> Waller RG, Scanlon KM, Robinson LF (2011) Cold-water coral distributions in the Drake Passage area from towed camera observations: initial interpretations. PLoS One 6(1):e16153

Wareham VE, Edinger EN (2007) Distribution of deep-sea corals in the Newfoundland and Labrador region, Northwest Atlantic Ocean. Bull Mar Sci 81:289-313

Williams GC (2011) The global diversity of sea pens (Cnidaria: Octocorallia: Pennatulacea). PLoS One 6(7): e22747

Zedel L, Fowler WA (2009) Comparison of boundary layer current profiles in locations with and without corals in Haddock Channel, southwest Grand Banks. In: Gilkinson K, Edinger EN (eds) The ecology of deep-sea corals of Newfoundland and Labrador waters: biogeography, life history, biogeochemistry, and relation to fish. Can Tech Rep Fish Aquat Sci 2830

Submitted: April 20, 2011; Accepted: October 11, 2011

Proofs received from author(s): January 7, 2012 